\title{
Prognostic factors in glomerular diseases with crescents
}

\author{
HASAN HACI YETER ${ }^{1}$, IPEK GONUL ${ }^{2}$, ERTUGRUL DEMIREL ${ }^{3}$, BERFU KORUCU ${ }^{1}$, ULVER DERICI ${ }^{1}$ \\ ${ }^{1}$ Department of Nephrology, Gazi University, Ankara, Turkey \\ ${ }^{2}$ Department of Pathology, Gazi University, Ankara, Turkey \\ ${ }^{3}$ Internal Medicine, Gazi University, Ankara, Turkey
}

\begin{abstract}
Introduction. More than $50 \%$ of glomerular crescent formation is required for a diagnosis of crescentic glomerulonephritis in a kidney biopsy. Although treatment protocols have been established for diffuse crescentic glomerulonephritis, there is no standard treatment for patients with fewer crescents in renal biopsies. In this study the importance of crescent percentage and clinical features on renal survival independent of underlying disease was investigated.

Methods. This retrospective observational study was conducted between 2013 and 2017. Forty-nine patients with crescent formation in their kidney biopsies were evaluated. We compared clinicopathological features and renal survival. We evaluated the factors affecting the course of end stage renal disease (ESRD).

Results. A total of 49 patients (57\% male and median age 49 years) were enrolled in this study. $39 \%$ of patients developed ESRD at follow-up. Logistic regression analysis showed that the requirement for renal replacement treatment on admission $(\mathrm{p}<0.001)$, serum creatinine level above $2.7 \mathrm{mg} / \mathrm{dL}(\mathrm{p}<0.001)$, the presence of more than $50 \%$ glomerulosclerosis $(\mathrm{p}=0.04)$ and more than $34 \%$ crescent formation $(\mathrm{p}=0.002)$ were significantly associated with ESRD. Kaplan-Meier survival analysis revealed that patients with less than $34 \%$ crescent in kidney biopsy and a serum creatinine level less than $2.7 \mathrm{mg} / \mathrm{dL}$ had increased kidney survival (log-rank test p: 0.01 and p: 0.002).

Conclusion. Patients with crescent formation in kidney biopsy more than $34 \%$ should be evaluated for more aggressive treatment modalities regardless of the underlying disease, especially if the serum creatinine level is above $2.7 \mathrm{mg} / \mathrm{dL}$.
\end{abstract}

Key words: Acute kidney injury, glomerulonephritis, glomerulosclerosis, kidney failure, treatment outcome.

\section{INTRODUCTION}

Crescent formation is a histological manifestation of severe glomerular damage, which is characterized by the presence of at least 2 layers of cells that are filling totally or partially the Bowman's space derived from proliferating and de-differentiated visceral and parietal cells [1]. These cells surround and compress the glomerular tuft [2]. Crescent formation appears as a result of non-specific response to severe injury to the glomerular capillary walls mediated by macrophages, $\mathrm{T}$ cells and proinflammatory cytokines [3]. This non-specific inflammatory process can be seen in many forms of glomerular diseases such as anti-glomerular basement membrane antibody disease (anti-GBM), systemic lupus erythematosus, IgA glomerulonephritis, membranoproliferative glomerulonephritis and ANCAassociated vasculitides $[4,5]$. If the crescent formation is detected in more than $50 \%$ glomeruli in the biopsy, it is called as crescentic glomerulonephritis (CrGN) or rapidly progressive glomerulonephritis (RPGN). Within few weeks, CrGN can lead to end stage renal disease (ESRD) or even death [5].
Kidney biopsy is not only the gold standard diagnostic test for glomerulonephritis, but it also has a prognostic value in patient with crescent formation in a biopsy sample. The severity of the disease is related to the percentage of crescent formation in the biopsy [5]. More than $80 \%$ crescent formation suggests an advanced renal failure and poor treatment response. On the other hand, less than $50 \%$ crescent formation is thought to be related to better kidney survival and treatment response [3, 6-8].

In the present study, we evaluated the contribution of possible histopathological and clinical risk factors including the presence of crescents, glomerulosclerosis, tubular atrophy/interstitial fibrosis in the biopsy, dialysis dependence and serum creatinine level on patients' admission for the development of ESRD in patients with different glomerular diseases.

\section{MATERIALS AND METHODS}

This retrospective study was conducted in the Department of Nephrology, Gazi University Medical 
School, Ankara. A total of 64 kidney biopsies with crescents from 820 kidney biopsies between 2013 and 2017, which were performed in our department, were selected for this study. Out of these, patients with a follow-up period of less than 6 months, patients who were not given an immunosuppressive treatment or those who failed to complete their treatment and glomerulonephritis secondary to infections or monoclonal disease were excluded. Finally, we included 49 patients in this study. All the procedures performed in studies involving human participants were in accordance with the 1964 Helsinki Declaration and its later amendments or comparable ethical standards. Written informed consent was obtained from all participants.

For all patients, the primary histopathological diagnosis, the percentage of crescents and glomerulosclerosis, the degree of tubular atrophy/interstitial fibrosis and immunofluorescence staining characteristics reported in the biopsy reports were recorded. Patients' demographics, clinical presentation, the course of disease, blood test results and treatment regimens were retrieved from hospital's electronic medical recording system. Serum levels of creatinine and albumin, estimated glomerular filtration ratio (eGFR), and 24-hour urine protein on admission and at the $6^{\text {th }}$ and $12^{\text {th }}$ months of follow-up and at the last clinical visit were determined for all patients.

Renal biopsy cores had been obtained with ultrasonography guided standard procedure. Fresh biopsy cores had been divided under the microscope for light microscopy and immunofluorescence microscopy. Following fixation in buffered formalin and routine tissue processing, paraffine embedded, 2-3 $\mu \mathrm{m}$ sections had been stained with hematoxylin eosin, Congo red, Masson's trichrome, Periodic acid-Schiff (PAS), Periodic acid-methenamine silver (Jones) stains. Immunofluorescence had been performed on unfixed, cryostat sections of kidney biopsy transported to the pathology laboratory on saline-soaked gauze. Fluorescein-labeled antibodies against immunoglobulins (IgG, IgM, IgA), complement components $(\mathrm{C} 3, \mathrm{C} 4, \mathrm{C} 1 \mathrm{q})$ and, kappa and lambda light chains had been used. All renal biopsy specimens were re-assessed light microscopically by the same nephropathologist blinded to patients. Electron microscopy could not be used in the study due to the lack of it in our department.

Patients were divided into three categories according to diagnosis. (1) Anti-glomerular basement membrane antibody disease (anti-GBM), (2) Immune complex diseases and IgA nephropathy, henoch schonlein purpura, membranoproliferative glomerulonephritis (immune complex mediated and $\mathrm{C} 3$ glomerulopathy), diffuse proliferative glomerulonephritis and systemic lupus erythomatosus) (3) Pauci-immune diseases (Wegener granulomatosis, microscopic polyangitis and ANCA negative pauci immune) Treatment protocols were decided according to the Kidney Disease Improving Global Outcomes (KDIGO) 2012 GN guidelines [9] and European Vasculitis Study Group (EUVAS) [10] for each diagnostic disease category. Intravenous (Iv) pulse prednisolone $500 \mathrm{mg} / \mathrm{d}$ (total dosage $3000 \mathrm{mg}$ ) + cyclophosphamide $500 \mathrm{mg}$ with 15 days interval (total dosage $6000 \mathrm{mg}$ ) + maintenance oral prednisolone treatment regimen used for CrGN. Rituximab was used in the case of cyclophosphamide resistance or the presence of a progressive disease. Plasma exchange was used in patients with alveolar hemorrhage.

Data distribution and homogeneity were determined by Kolmogorov-Smirnov test and oneway-anova test. If the distribution was heterogeneous, variables were shown as median (minimummaximum). Categorical variables are expressed as percentage. For data that were not normally distributed, the Mann-Whitney $U$ test was used if only two groups were compared; The KruskalWallis one-way analysis of variance was used if more than two groups were being compared. Receiver operating curve (ROC) analysis was plotted to illustrate the best cut-off values crescent percentage and serum creatinine levels for the estimation of ESRD. Logistic regression was used to identify variables that predict ESRD. The development of ESRD was analyzed with KaplanMeier analysis. p Values less than 0.05 were considered statistically significant. Analyses were performed with Statistical Package for the Social Science (SPSS version 20.0.0, IBM, Armonk, NY) software for Windows.

\section{RESULTS}

A total of 49 patients $(57 \%$ male and $43 \%$ female) were enrolled in this study and median age was 47 years old. Thirty-nine percent of patients (19 out of 49) developed ESRD at follow-up. The most frequent diagnosis was pauci-immune glomerulonephritis (61\%). While, crescent and glomerulosclerosis percentage were significantly higher in 
ESRD patients $(\mathrm{p}=0.04$ and $\mathrm{p}=0.03$, respectively), tubular atrophy/interstitial fibrosis was similar $(\mathrm{p}=0.5)$ (Table 1$)$. Gender and age distribution were similar between diagnosis group $(\mathrm{p}=0.1$ and $\mathrm{p}=0.18)$. Patients' serum creatinine levels were significantly higher in anti-GBM group on admission $(p=0.02)$. In the follow-up of patients serum creatinine, albumin, eGFR and urine protein were similar between groups. Although, crescent percentage was significantly higher in patients with anti GBM ( $\mathrm{p}<0.001)$, glomeruloclerosis percentage and tubular atrophy were similar between groups $(\mathrm{p}=0.4$ and $\mathrm{p}=0.6)$. While, cyclophosphamide treatment was administered to 30 of $49(61 \%)$ patients, plasma exchange treatment was administered to 11 of $49(22 \%)$, steroid treatment was administered to 47 of $49(96 \%)$ patients. Laboratory and treatment modalities of patients were shown in Table 2 . When the patients were grouped as diffuse CrGN and non diffuse $\mathrm{CrGN}$, it has shown that all the patients diagnosed with anti GBM disease and $43 \%$ of total pauci immune glomerulonephritis were CrGN. On the other hand, all the patients diagnosed with immune complex glomerulonephritis were non diffuse CrGN (Table 3).

ROC analysis was used to determine the best cutoff value of crescent percentage and serum creatinine level for ESRD. More than 34\% crescent in kidney biopsy (sensitivity $=73 \%$, specificity $=$ $74 \%$, positive predictive value (PPV): $69 \%$, negative predictive value (NPV): $73 \%$ and $\mathrm{AUC}=0.74$,
95\% confidence interval (Cl) $0.601-0.887$ ) and serum creatinine level of $2.7 \mathrm{mg} / \mathrm{dL}$ (sensitivity $=$ $83 \%$ and specificity $=87 \%$, PPV: $81.2 \%$, NPV: $86.7 \%$ and $\mathrm{AUC}=0.91,95 \% \mathrm{Cl}: 0.835-0.993$ ) were the best values associated with ESRD. Univariate logistic regression was used to analyze independent risk factors for ESRD (Table 4). RRT, [odds ratio (OR) 81.200, 95\% Cl 8.646-762.569, $\mathrm{p}<0.001]$, serum creatinine level of more than $2.7 \mathrm{mg} / \mathrm{dL}$ (OR: 34.667, 95\% Cl 6.851-175.406, $\mathrm{p}<0.001$ ), glomerulosclerosis more than $50 \%$ (OR: 4.800, 95\% Cl 1.063-21.676, $\mathrm{p}=0.04$ ) and crescent percentage above 34\% (OR: $7.700,95 \%$ $\mathrm{Cl} 2.092-28.335, \mathrm{p}=0.002$ ) were significantly associated with ESRD. However, patient's age, serum albumin concentration, presence of glomerulosclerosis less than $50 \%$ on kidney biopsy and tubular atrophy/interstitial fibrosis were not significantly associated with ESRD in logistic regression analysis [p $=0.2$ (for 31-50 years), $\mathrm{p}=0.5$ (for 51-60 years), $\mathrm{p}=0.6$ (for $>60$ years); $\mathrm{p}=0.1$ (for albumin $<$ $2 \mathrm{mg} / \mathrm{dL}$ ), $\mathrm{p}=0.8$ (for albumin $2.5-3.5 \mathrm{mg} / \mathrm{dL}$ ); $\mathrm{p}=$ 0.4 (for $25-50 \%$ glomerulosclerosis); $\mathrm{p}=0.3$, respectively)].

Kaplan-Meier survival analysis revealed that patients with less than $34 \%$ crescent in kidney biopsy and serum creatinine level of less than $2.7 \mathrm{mg} / \mathrm{dL}$ had increased kidney survival as compared to patients with more than $34 \%$ crescent in kidney biopsy and serum creatinine concentration more than $2.7 \mathrm{mg} / \mathrm{dL}$ (log-rank test $\mathrm{p}: 0.01$ and p: 0.002, respectively) (Figure 1).

Table 1

Demographic parameters and biopsy findings of patients

\begin{tabular}{|c|c|c|c|c|}
\hline & \multicolumn{4}{|c|}{ ESRD } \\
\hline & $\begin{array}{l}\text { Total } \\
\mathrm{n}=49\end{array}$ & $\begin{array}{c}\text { Yes } \\
\mathrm{n}=19(39 \%)\end{array}$ & $\begin{array}{c}\text { No } \\
\mathrm{n}=30(61 \%)\end{array}$ & p value \\
\hline Gender (Male) n (\%) & $28(57 \%)$ & $12(63 \%)$ & $16(53 \%)$ & 0.5 \\
\hline Age (years) & $47(19-83)$ & $38.5(20-67)$ & $52(21-68)$ & 0.1 \\
\hline $\begin{array}{l}\text { Diagnosis group n (\%) } \\
\text { - anti GBM disease } \\
\text { - Immune complex } \\
\text { - Pauci immune }\end{array}$ & $\begin{array}{l}5(10 \%) \\
14(29 \%) \\
30(61 \%)\end{array}$ & $\begin{array}{c}4(80 \%) \\
2(14 \%) \\
13(43 \%)\end{array}$ & $\begin{array}{l}1(20 \%) \\
12(86 \%) \\
17(57 \%)\end{array}$ & $\begin{array}{c}\mathbf{0 . 0 4} \\
\mathbf{0 . 0 5} \\
0.4\end{array}$ \\
\hline $\begin{array}{l}\text { Histopathology } \\
\text { Crescent (\%) } \\
\text { Glomerulosclerosis (\%) } \\
\text { Tubular atrophy (n) }\end{array}$ & $\begin{array}{c}31(3.7-100) \\
31(0-100) \\
35(71 \%)\end{array}$ & $\begin{array}{c}52(8-100) \\
32(0-100) \\
15(79 \%)\end{array}$ & $\begin{array}{c}18.3(3.7-100) \\
25.7(0-66.7) \\
20(67 \%)\end{array}$ & $\begin{array}{c}\mathbf{0 . 0 4} \\
\mathbf{0 . 0 3} \\
0.5\end{array}$ \\
\hline RRT n (\%) & $15(31 \%)$ & $14(74 \%)$ & $1(3 \%)$ & $<0.001$ \\
\hline Duration of follow-up (month) & $20(6-79)$ & $9.5(6-72)$ & $24(6-79)$ & 0.4 \\
\hline
\end{tabular}

ESRD: end stage renal disease; GBM: Glomerular basement membrane; RRT: renal replacement treatment. 
Table 2

Laboratory, demographics and treatment modalities of patients

\begin{tabular}{|c|c|c|c|c|c|}
\hline \multicolumn{6}{|c|}{ Diagnosis } \\
\hline & $\begin{array}{c}\text { Total } \\
\mathrm{n}=49\end{array}$ & $\begin{array}{c}\text { Anti-GBM } \\
\mathrm{n}=\mathbf{5}(\mathbf{1 0} \%)^{*}\end{array}$ & $\begin{array}{c}\text { Immune complex } \\
n=14(29 \%)\end{array}$ & $\begin{array}{c}\text { Pauci immune } \\
n=30(61 \%)\end{array}$ & p value \\
\hline Gender (Male) n(\%) & $28(57 \%)$ & $5(100 \%)$ & $7(50 \%)$ & $16(53 \%)$ & 0.1 \\
\hline Age (years) & $49(19-83)$ & $24(19-83)$ & $49(25-61)$ & $49.5(20-68)$ & 0.2 \\
\hline $\begin{array}{l}\text { Laboratory Parameters (Diagnosis) } \\
\text { - } \quad \text { Crea }(\mathrm{mg} / \mathrm{dL}) \\
\text { - } \\
\text { - } \operatorname{AgFR}\left(\mathrm{mL} / \mathrm{min} / 1.73 \mathrm{~m}^{2}\right) \\
\text { - } \\
\text { - Urine protein }(\mathrm{g} / \mathrm{d}) \\
\end{array}$ & $\begin{array}{l}2.19(0.5-10.4) \\
29.5(5-125) \\
3.4(1.88-4) \\
3.2(0.2-26.6)\end{array}$ & $\begin{array}{l}3.5(2.5-5.8) \\
23(16-33) \\
3.2(2.5-3.6) \\
4(0.5-26.6)\end{array}$ & $\begin{array}{c}1.64(0.8-4.9) \\
40(10-115) \\
3.6(2.3-3.9) \\
3.3(1-7.2)\end{array}$ & $\begin{array}{l}2.6(0.5-10.4) \\
27(5-125) \\
3.4(1.88-4) \\
3.2(0.2-19)\end{array}$ & $\begin{array}{c}\mathbf{0 . 0 2} \\
\mathbf{0 . 0 3} \\
0.5 \\
0.8\end{array}$ \\
\hline 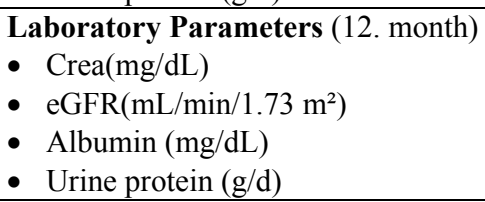 & $\begin{array}{l}1.5(0.4-13.4) \\
43(5-133) \\
4.2(3.3-4.8) \\
0.7(0.2-8.8)\end{array}$ & $\begin{array}{l}5.8(5-6.6) \\
8(6-10) \\
3.5(3-4)\end{array}$ & $\begin{array}{l}1.3(0.7-3.6) \\
58(22-116) \\
4.2(3.3-4.8) \\
0.7(0.2-8.8)\end{array}$ & $\begin{array}{l}2.3(0.4-13.4) \\
29.5(5-133) \\
4.2(3.8-4.5) \\
0.7(0.2-4.4)\end{array}$ & $\begin{array}{l}0.1 \\
0.1 \\
0.3 \\
0.7\end{array}$ \\
\hline $\begin{array}{l}\text { Laboratory Parameters (Last) } \\
\text { - } \quad \text { Crea }(\mathrm{mg} / \mathrm{dL}) \\
\text { - } \\
\text { - } \operatorname{eGFR}\left(\mathrm{mL} / \mathrm{min} / 1.73 \mathrm{~m}^{2}\right) \\
\text { - } \\
\text { - }\end{array}$ & $\begin{array}{l}1.6(0.5-12.8) \\
41(5-126) \\
4(3.2-4.9) \\
0.5(0.1-11.5)\end{array}$ & & $\begin{array}{l}1.19(0.8-5.6) \\
55(8.1-113) \\
4.2(3.2-4.9) \\
0.2(0.1-1.5)\end{array}$ & $\begin{array}{l}1.98(0.5-12.8) \\
37(5-126) \\
4.2(3.8-4.5) \\
0.5(0.1-11.5)\end{array}$ & $\begin{array}{c}0.06 \\
0.07 \\
0.5 \\
0.2\end{array}$ \\
\hline $\begin{array}{l}\text { Histopathology } \\
\text { Crescent (\%) } \\
\text { Glomerulosclerosis (\%) } \\
\text { Tubular atrophy (n) }\end{array}$ & $\begin{array}{c}31(3.7-100) \\
31(0-100) \\
35(71 \%)\end{array}$ & $\begin{array}{c}55(45-92) \\
24(0-79) \\
3(60 \%)\end{array}$ & $\begin{array}{c}9.7(3.7-45) \\
41(0-89) \\
9(64 \%)\end{array}$ & $\begin{array}{c}38(9-100) \\
28(0-100) \\
23(77 \%)\end{array}$ & $\begin{array}{c}<\mathbf{0 . 0 0 1} \\
0.4 \\
0.6\end{array}$ \\
\hline $\begin{array}{l}\text { Treatment } \\
\text { - } \text { Cyclophosphamide } \\
\text { - } \text { PEX } \\
\text { - Steroid } \\
\text { - } \text { MMF } \\
\text { - CNI } \\
\text { - Aza } \\
\text { - } \text { RTX }\end{array}$ & $\begin{array}{c}30(61 \%) \\
11(22 \%) \\
47(96 \%) \\
5(11 \%) \\
1(2 \%) \\
5(11 \%) \\
3(6 \%)\end{array}$ & $\begin{array}{c}3(60 \%) \\
4(80 \%) \\
3(60 \%) \\
0 \\
0 \\
0 \\
0\end{array}$ & $\begin{array}{c}2(14 \%) \\
0 \\
14(100 \%) \\
2(14 \%) \\
1(17 \%) \\
0 \\
0\end{array}$ & $\begin{array}{c}25(83 \%) \\
7(23 \%) \\
30(100 \%) \\
3(10 \%) \\
0 \\
5(16 \%) \\
3(10 \%)\end{array}$ & \\
\hline ESRD & $19(39 \%)$ & $4(80 \%)$ & $2(14 \%)$ & $13(43 \%)$ & 0.02 \\
\hline
\end{tabular}

GBM: Glomerular basement membrane; Crea: creatinine; eGFR: estimated glomerular filtration rate; PEX: plasma exchange; MMF:mycophenolate mofetil; CNI: calcineurin inhibitor; Aza: azathioprine; RTX: rituximab; ESRD: end stage renal disease.

*n: 2 for 12 months follow-up.

Table 3

Demographic and diagnostic distribution of patients according to rapidly progressive glomerulonephritis

\begin{tabular}{|c|c|c|c|c|}
\hline & $\begin{array}{c}\text { Total } \\
\mathrm{n}=49\end{array}$ & $\begin{array}{c}\text { Crescent }<50 \% \\
\text { n }=31(63 \%)\end{array}$ & $\begin{array}{c}\text { Crescent }>50 \% \\
n=18(37 \%)\end{array}$ & p value \\
\hline Gender Male/Female & $28(57 \%) / 21(43 \%)$ & $17(55 \%) / 14(45 \%)$ & $11(61 \%) / 7(39 \%)$ & 0.4 \\
\hline Age & $47(19-83)$ & $51(21-68)$ & $34.5(19-83)$ & 0.1 \\
\hline anti GBM disease (n) & $5(10 \%)$ & 0 & 5 & \\
\hline Immune complex (n) & $14(29 \%)$ & 14 & 0 & \\
\hline IgAN & 6 & 6 & 0 & \\
\hline SLE & 3 & 3 & 0 & \\
\hline DPGN & 2 & 2 & 0 & \\
\hline HSP & 1 & 1 & 0 & \\
\hline MPGN (C3 GP) & 2 & 2 & 0 & \\
\hline Pauci immune (n) & $30(61 \%)$ & 17 & 13 & \\
\hline WG & 21 & 12 & 9 & \\
\hline mPAN & 5 & 3 & 2 & \\
\hline ANCA negative & 4 & 2 & 2 & \\
\hline ESRD & $19(39 \%)$ & $7(23 \%)$ & $12(67 \%)$ & 0.005 \\
\hline
\end{tabular}

anti GBM: anti glomerular basal membrane, IgAN:IgA nephropathy, SLE: systemic lupus erythematosus, DPGN: diffuse proliferative glomerulonephritis, HSP: henoch schonlein purpura, MPGN: membranoproliferative glomerulonephritis, C3GP: C3 glomerulopathy, WG: wegener granulomatosus, mPAN: microscopic polyangitis, ANCA: anti nuclear anti body. 
Table 4

Univariate logistic regression analysis for possible predictors of ESRD

\begin{tabular}{|c|c|c|c|}
\hline & \multicolumn{2}{|c|}{ Univariate logistic regression analysis } & \multirow[b]{2}{*}{ P value } \\
\hline & Odds ratio & 95\% Confidence interval & \\
\hline Gender & 0.889 & $0.262-3.013$ & 0.8 \\
\hline $\begin{array}{l}\text { Age } \\
\text { - } 18-30 \\
\text { - } 31-50 \\
\text { - } 51-60 \\
\text { - }>60\end{array}$ & $\begin{array}{c}\text { ref. } \\
3.500 \\
1.944 \\
1.556\end{array}$ & $\begin{array}{c}\text { ref. } \\
0.473-25.901 \\
0.287-13.188 \\
0.218-11.086\end{array}$ & $\begin{array}{l}\text { ref. } \\
0.2 \\
0.5 \\
0.6\end{array}$ \\
\hline RRT & 81.200 & $8.646-762.569$ & $<0.001$ \\
\hline $\begin{array}{l}\text { Albumin }(\mathrm{mg} / \mathrm{dL}) \\
\text { - } \quad<2.5 \\
\text { - } 2.5-3.5 \\
\text { - }>3.5\end{array}$ & $\begin{array}{c}4.333 \\
0.867 \\
\text { ref. }\end{array}$ & $\begin{array}{c}0.614-30.570 \\
0.224-3.355 \\
\text { ref. }\end{array}$ & $\begin{array}{l}0.1 \\
0.8 \\
\text { ref. }\end{array}$ \\
\hline $\begin{array}{l}\text { Creatinine }(\mathrm{mg} / \mathrm{dL})^{*} \\
\text { - } \quad>2.7\end{array}$ & 34.667 & $6.851-175.406$ & $<0.001$ \\
\hline $\begin{array}{l}\text { Glomerulosclerosis } \\
\text { - } \quad<25 \\
\text { - } 25-50 \\
\text { - }>50\end{array}$ & $\begin{array}{l}\text { ref. } \\
1.800 \\
4.800\end{array}$ & $\begin{array}{c}\text { ref. } \\
0.430-7.532 \\
1.063-21.676\end{array}$ & $\begin{array}{c}\text { ref. } \\
0.4 \\
\mathbf{0 . 0 4}\end{array}$ \\
\hline Tubular atrophy & 1.875 & 0.491 .7 .153 & 0.3 \\
\hline $\begin{array}{l}\text { Crescent*** } \\
\text { - }>34 \%\end{array}$ & 7.700 & $2.092-28.335$ & 0.002 \\
\hline
\end{tabular}

*ROC analysis was performed to find best cutoff value of serum creatinine for ESRD: $2.7 \mathrm{mg} / \mathrm{dL}$ sens: $83 \%$, spec: $87 \%$ positive predictive value: $81.2 \%$, negative predictive value: $86.7 \%$ and AUC: $0.91,95 \% \mathrm{Cl}: 0.835-0.993$.

**ROC analysis was performed to find the best cutoff value of crescent percentage for ESRD $>34 \%$ sens: $73 \%$, spec: $74 \%$, positive predictive value: $69 \%$, negative predictive value: $73 \%$ and AUC: $0.74,95 \% \mathrm{Cl} 0.601-0.887$.

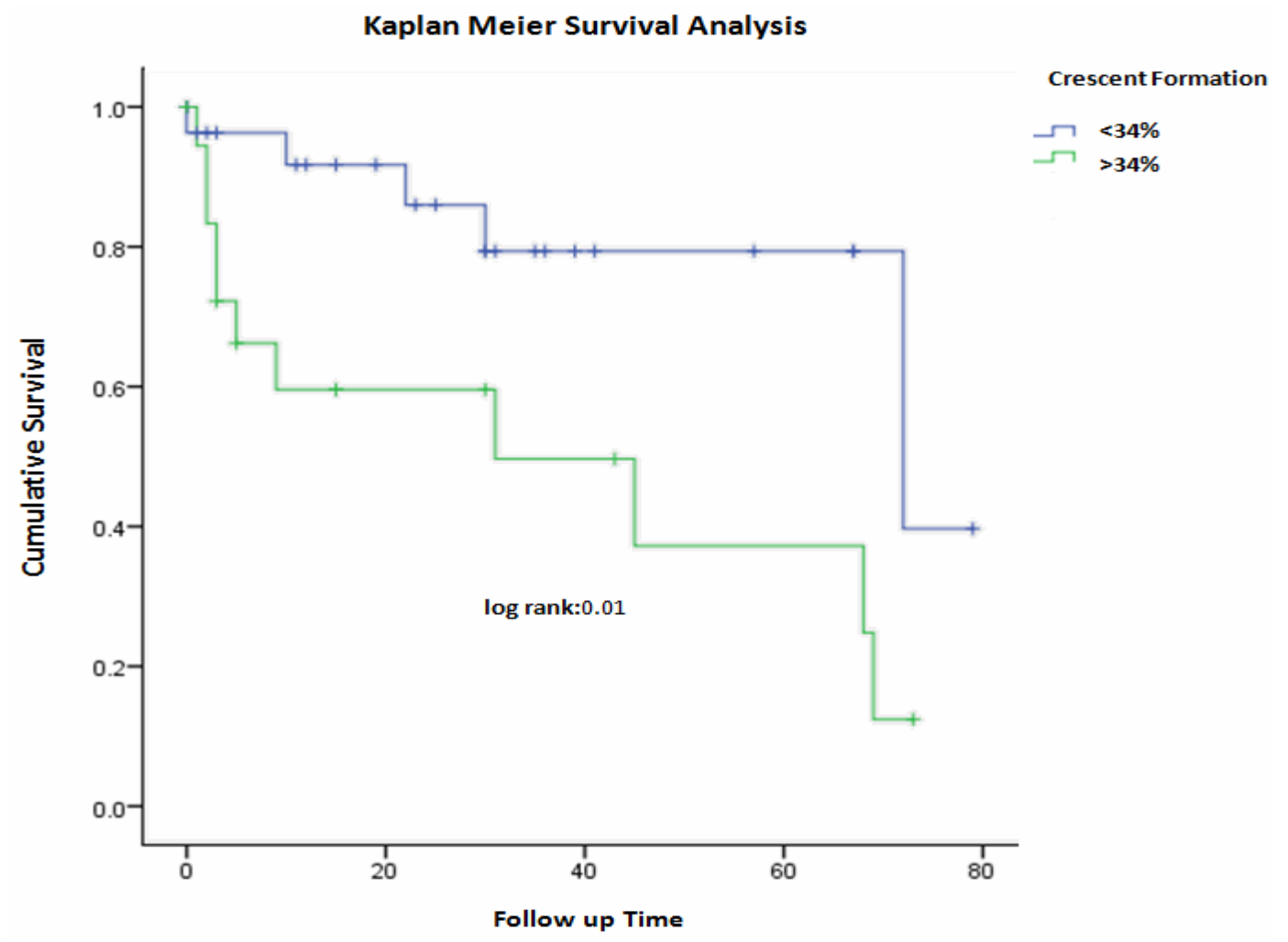




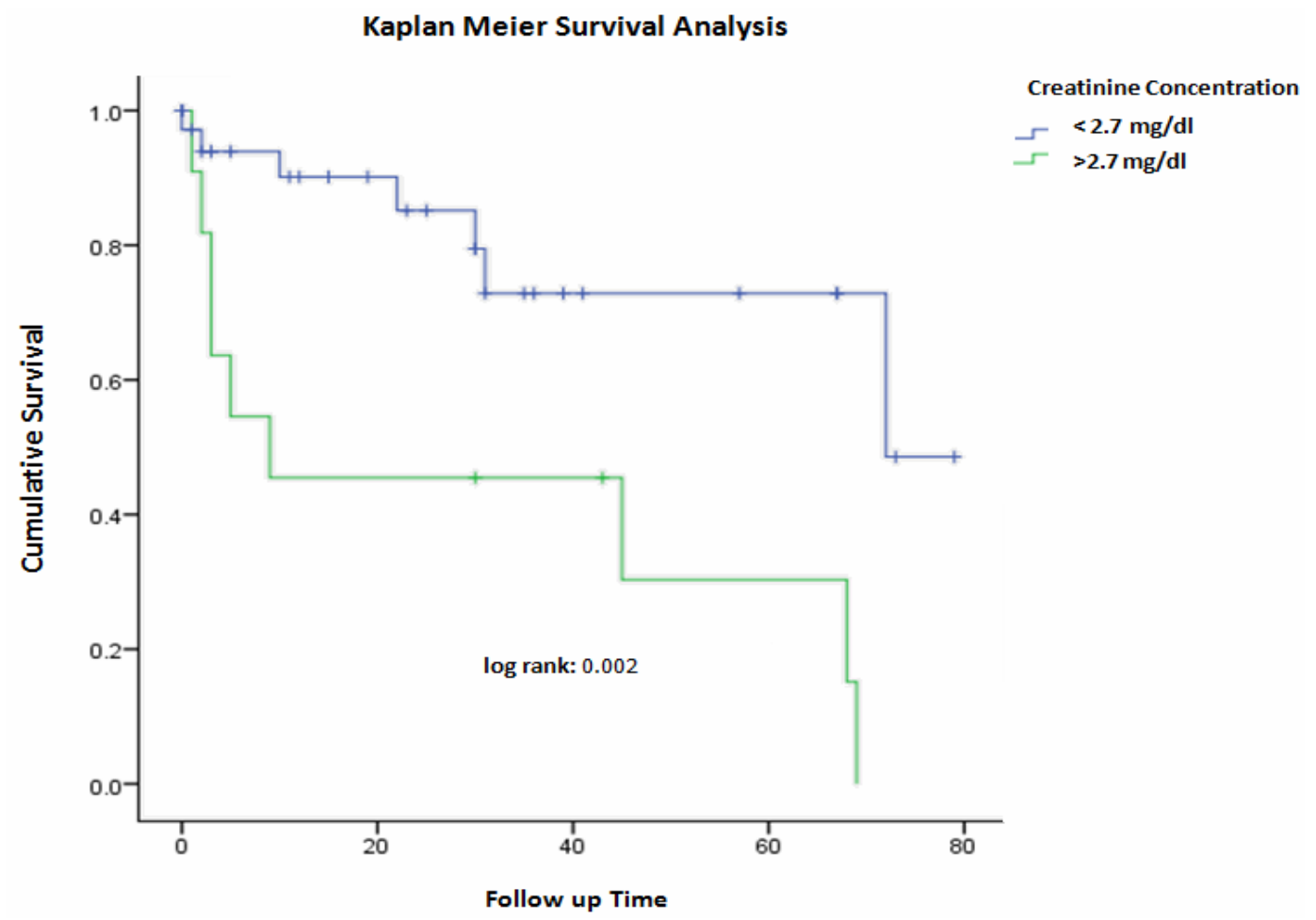

Figure 1: Kaplan Meier survival analysis: ESRD development according to the crescent formation and serum creatinine concentration.

\section{DISCUSSION}

In our study, pauci immune glomerulonephritis was the most common diagnosis group, which is presented with crescent formation in kidney biopsy. All the patients with anti GBM disease met the diffuse $\mathrm{CrGn}$ criteria. While, almost half of patients with pauci immune group met diffuse CrGN criteria, all the patients with immune complex glomerulonephritis had less than $50 \%$ crescent in kidney biopsy.

The present study showed that more than $\% 34$ crescent formation in kidney biopsy need for RRT in the presentation of the disease, serum creatinine level above $2.7 \mathrm{mg} / \mathrm{dL}$ on admisson are predictors of ESRD in patients with crescent formation in kidney biopsy. Risk factors affecting renal prognosis in CrGN are high serum creatinine, dialysis dependence on admission and more than $80 \%$ crescent formation in kidney biopsy, glomerulosclerosis and tubular atrophy [2, 11-13]. In a series of 71 patients with anti GBM disease, it has been shown that serum creatinine level of $\leq 5.7 \mathrm{mg} / \mathrm{dL}$ on admission was associated with 95\% kidney survival [14]. Similar to these result, Heilman et al. showed that patients with a serum creatinine level of $\geq 6 \mathrm{mg} / \mathrm{dL}$ on admission is associated with worse kidney outcome in patients with immune complex CrGN [12]. Many studies in the literature support similar results $[11,12,15]$. Besides, our study also demonstrated that more than $50 \%$ glomerulosclerosis in kidney biopsy associated with ESRD development. Berden et al. showed that more than $50 \%$ glomerulosclerosis in kidney biopsy is a predictor decreased kidney survival in patients with pauci immune CrGN. An important part of the studies in the literature designed according to diffuse CrGN definition and cutoff crescent formation was determined as $\% 50$. The present study separated from these studies by determining the factors predicting the ESRD with the presence of any percentage of crescent formation in kidney biopsy.

Clinical importance of glomerular crescent formation has been demonstrated in the 1970s [16]. It is recognized that the patients with cellular crescent formation in more than $>80 \%$ glomeruli usually progresses to renal failure rapidly and it was named as malignant glomerulonephritis $[5,16]$. Later, it became necessary to re-define malignant glomerulonephritis based on the fact that nearly one half of patients did not develop ESRD in their follow-up [17]. In 1987, Baldwin et al. demonstrated that patients with crescents in less than $50 \%$ of glomeruli in their kidney biopsies may follow a more indolent course and may even undergo remission [5]. After that, $\mathrm{CrGN}$ is re-defined by the 
presence of more than $50 \%$ of glomerular crescents in renal biopsy and these histological findings were accepted as a marker of rapid deterioration of renal function $[4,18,19]$. In the present study, we showed that more than $34 \%$ crescent formation in renal biopsy, regardless of the underlying glomerular disease, is a strong predictor of ESRD. In addition Kaplan-Meier survival analysis strongly supports that patients with less than $34 \%$ crescent formation in their biopsy had increased kidney survival during the median 20 months follow-up.

Our study has some important limitation. First of all, our patients' group is small. Therefore, we could not evaluate the factors affecting ESRD development by multivariate analysis. Secondly, we have no detailed information on some interventions and medical conditions (e.g., dosage and duration of immunosuppressive drugs, infections causing the treatment interruption, an exacerbation of underlying disease). Studies addressing these limitations with larger sample sizes are needed to evaluate the crucial effect of crescent formation on the development of ESRD.

\section{CONCLUSION}

In conclusion, need for renal replacement therapy on admission, creatinine concentration higher than $2.7 \mathrm{mg} / \mathrm{dL}$, and crescent formation in more than $34 \%$ of all glomerulus in kidney biopsy seems to be important predictors for prognosis of patients with crescent formation in kidney biopsy regardless of the underlying disease.

Acknowledgement. There is no funding.

Declaration of interest. The authors declare that there is no conflict of interest.

Introducere. Pentru diagnosticul glomerulonefritei membranoproliferative este necesar ca la biposia renală să fie identificate mai mult de $50 \%$ de semilune în cadrul nefronilor. Deși există standarde de diagnostic pentru tratamentul acestei entități totuşi $n u$ există o abordare standard terapeutică pentru pacienții care prezintă semilune într-un procent mai scăzut. Scopul studiului este de a evalua parametrii clinici şi prognostici la aceşi pacienți.

Materiale şi metode. A fost realizat un studiu observațional retrospectiv între 2013-2017. Au fost evaluați 49 de pacienți cu semilune prezente la biopsia renală. Au fost comparate aspecte clinice şi histopatologice precum şi supraviețuirea acestor pacienți.

Rezultate. 57\% dintre pacienți au fost de gen masculin. Media vârstei a fost de 49 de ani. 39\% dintre pacienți au dezvoltat BCR (boală cronică renală). Modelul de regresie logistică a identificat necesitatea terapiei de substituție renală la internare, alături de nivelul creatininei peste $2.7 \mathrm{mg} / \mathrm{dL}$, de prezența a cel puțin $50 \%$ de nefroni cu glomeruloscleroză şi de un procent mai mare de $34 \%$ de semilune ca predictor independenti pentru dezvoltarea BCR. Curba de supravietuire Kaplan-Meier a arătat că pacienții cu un procent mai mic de $34 \%$ de semilune la biopsia renală şi cu valorea creatininei sub $2.7 \mathrm{mg} / \mathrm{dL}$ au avut o supraviețuire mai bună (test log rank, $p=0.01$ respectiv $p=0.002$ ).

Concluzii. Pacienții cu semilune în procent mai mare de $34 \%$ ar trebui tratați mai agresiv mai ales dacă nivelul creatininei este peste $2.7 \mathrm{mg} / \mathrm{dL}$.

Correspondence to: Hasan Hac1 YETER, MD, Department of Nephrology,

Gazi University Medical School, Ankara, Turkey, Tel: + 905542397449

E-mail: hasanyeter@hotmail.com

\section{REFERENCES}

1. HÉNIQUE C, PAPISTA C, GUYONNET L, LENOIR O, THARAUX P-L. Update on crescentic glomerulonephritis. Semin Immunopathol. 2014;36(4):479-490.

2. MORONI G, PONTICELLI C. Rapidly progressive crescentic glomerulonephritis: early treatment is a must. Autoimmun Rev. 2014; 13(7): 723-729. 
3. BONSIB S-M. Glomerular basement membrane necrosis and crescent organization. Kidney Int. 1988; 33(5): 966-974.

4. QUIROGA B, VEGA A, RIVERA F, LOPEZ-GOMEY J. Crescentic glomerulonephritis: data from the Spanish Glomerulonephritis Registry. Intern Med J. 2015; 45(5): 557-562.

5. BALDWIN DS, NEUGARTEN J, FEINER H-D, GLUCK M, SPINOWITZ B. The existence of a protracted course in crescentic glomerulonephritis. Kidney Int. 1987; 31(3): 790-794.

6. JENNETTE J-C. Rapidly progressive crescentic glomerulonephritis. Kidney Int. 2003; 63(3): 1164-1177.

7. TARZI R-M, COOK H-T, PUSEY C-D. Crescentic glomerulonephritis: new aspects of pathogenesis. Semin Nephrol. 2011;31(4): 361-368.

8. ATKINS R-C, NIKOLIC-PATERSON D-J, SONG Q, LAN H-Y. Modulators of crescentic glomerulonephritis. J Am Soc Nephrol. 1996; 7(11): 2271-2278.

9. CATTRAN DC, FEEHALLY J, COOK HT, LIU ZH, FERVENZA FC, MEZZANO SA. et al. Kidney disease: improving global outcomes (KDIGO) glomerulonephritis work group. KDIGO clinical practice guideline for glomerulonephritis. Kidney Int Supp.2012; 2(2): 139-274.

10. ROBSON J, DOLL H, SUPPIAH R, FLOSSMANN O, HARPER L, HÖGLUND P. et al. Damage in the ANCA-associated vasculitides: long-term data from the European vasculitis study group (EUVAS) therapeutic trials. Ann Rheum Dis. 2015; 74(1): 177-184.

11. OZTURK R, YENIGUN EC, DEDE F, KOC E, TURGUT D, PISKINPASA S-V. et al. Prognostic factors in crescentic glomerulonephritis: a single-center experience. Iran J Kidney Dis. 2015; 9(1):31-38.

12. HEILMAN R-L, OFFORD K-P, HOLLEY K-E, VELOSA J-A. Analysis of risk factors for patient and renal survival in crescentic glomerulonephritis. Am J Kidney Dis. 1987; 9(2): 98-107.

13. BERDEN A-E, FERRARIO F, HAGEN E-C, JAYNE D-R, JENNETTE J-C, JOH K. et al. Histopathologic classification of ANCA-associated glomerulonephritis. J Am Soc Nephrol. 2010; 21(10): 1628-1636.

14. LEVY J-B, TURNER A-N, REES A-J, PUSEY C-D. Long-term outcome of anti-glomerular basement membrane antibody disease treated with plasma exchange and immunosuppression. Ann Intern Med. 2001; 134(11): 1033-1042.

15. WEIDNER S, GEUSS S, HAFEZI-RACHTI S, WONKA A, RUPPRECHT H-D. ANCA-associated vasculitis with renal involvement: an outcome analysis. Nephrol Dial Transpl. 2004; 19(6): 1403-1411.

16. SONSINO E, NABARRA B, KAZATCHKINE M, HINGLAIS N, KREIS H. Extracapillary proliferative glomerulonephritis so-called malignant glomerulonephritis. Adv Nephrol Necker Hosp. 1972; 2: 121.

17. WHITWORTH J-A, MOREL-MAROGER L, MIGNON F, RICHET G. The significance of extracapillary proliferation. Nephron. 1976; 16(1): 1-19.

18. CHOUDHURY T-A, SINGH R-G, SINGH S, SINGH T-B, RATHORE S-S. Clinicopathologic spectrum of crescentic glomerulonephritis: A hospital-based study. Saudi J Kidney Dis Transpl. 2014; 25(3): 689.

19. COUSER W-G. Rapidly progressive glomerulonephritis: classification, pathogenetic mechanisms, and therapy. Am J Kidney Dis. 1988 ; 11(6): 449-464.

Received March 9, 2019 